COOKBOOK POLITICS 



\section{COOKBOOK POLITICS}

\section{KENNAN FERGUSON}

\section{PENN}

University of Pennsylvania Press Philadelphia 
Copyright (C) 2020 University of Pennsylvania Press

All rights reserved. Except for brief quotations used for purposes of review or scholarly citation, none of this book may be reproduced in any form by any means without written permission from the publisher.

Published by

University of Pennsylvania Press

Philadelphia, Pennsylvania 19104-4112

www.upenn.edu/pennpress

Printed in the United States of America on acid-free paper $\begin{array}{lllllllllll}10 & 9 & 8 & 7 & 6 & 5 & 4 & 3 & 2 & 1\end{array}$

A Cataloging-in-Publication record is available from the Library of Congress

ISBN 978-0-8122-5226-2 